\title{
A BLOCKCHAIN-BASED ONLINE REVIEW SYSTEM OF TOURISM PRODUCTS USING ETHEREUM
}

\author{
Mohamad Rafi Raihan Rizal \\ Master Program of Technology and Engineering \\ Gunadarma University \\ www.gunadarma.ac.id \\ rafi.raihanrizal@yahoo.co.id
}

\begin{abstract}
Rapid technological advances have made blockchain technology applicable not only to digital money but in various fields. One of the areas that can be implemented by blockchain is digital tourism, specifically in the online review system of tourism products. The current online review system has several problems due to its centralized nature. The problem faced is the manipulation of review data which can be in the form of review deletion by a centralized party. This research proposes a decentralized online review system using the Ethereum blockchain technology, Smart Contracts, and IPFS to provide a secure, transparent, and trustworthy online review system platform. The purpose of this research is to implement a permission-less blockchain as storage for reviews (review forms and log notes) and develop a web application as a user interface. The data used is data from travel sites that contain details about hotels and restaurants in Bukhara. The results displayed are the development of a web application that implements a permission-less blockchain using Ethereum and the system performance is displayed based on system testing, which comprised of unit testing and Black-Box testing.
\end{abstract}

Keywords: Blockchain; Ethereum; Online Review System; Smart Contracts

Abstrak- Kemajuan teknologi yang sangat pesat
membuat teknologi blockchain tidak hanya dapat
diterapkan pada uang digital, melainkan pada
berbagai bidang. Salah satu bidang yang dapat
diimplementasikan oleh blockchain adalah
pariwisata digital, secara khusus pada sistem ulasan
online dari produk pariwisata. Sistem ulasan online
yang ada sekarang memiliki beberapa masalah
karena sifatnya yang tersentralisasi. Masalah yang
dihadapi yaitu manipulasi data ulasan yang dapat
berupa penghapusan ulasan oleh pihak yang
terpusat. Penelitian ini mengusulkan sistem ulasan
online yang terdesentralisasi dengan menggunakan
teknologi blockchain Ethereum, Smart Contracts, dan
IPFS untuk menyediakan platform sistem ulasan
online yang aman, transparan, dan dapat dipercaya.
Tujuan dari penelitian ini adalah untuk menerapkan
permission-less blockchain sebagai tempat penyimpanan ulasan (form ulasan dan catatan log) dan mengembangkan aplikasi web sebagai antarmuka pengguna. Data yang digunakan adalah data dari situs perjalanan yang berisi tentang detail hotel dan restoran di Bukhara. Hasil yang ditampilkan adalah pengembangan aplikasi web yang mengimplementasikan permission-less blockchain menggunakan Ethereum dan kinerja sistem ditampilkan berdasarkan pengujian sistem, yaitu pengujian unit dan pengujian Black-Box.

Kata Kunci: Blockchain; Ethereum; Sistem Ulasan Daring; Smart Contracts

\section{INTRODUCTION}

Almost every business, product, or service can now be reviewed or rated using online review platforms, including tourism products. Travel accommodation providers like Booking.com, TripAdvisor, and Airbnb are using popular online review systems as well as online shopping stores like Alibaba, eBay, and Amazon. Two of the most popular review websites out there are Yelp and TripAdvisor. According to statistical information on Alexa (2020), Yelp and TripAdvisor ranked as the $64^{\text {th }}$ and $118^{\text {th }}$ of the 500 most visited websites in the United States, respectively.

People believe that this ability to review businesses is vital to their rights as empowered consumers. Because of that, almost $40 \%$ of leisure travelers use travel-related websites such as TripAdvisor, Priceline, and Expedia to make a purchasing decision (Mccarthy et al., 2010), (ReyesMenendez et al., 2020). The businesses themselves also benefit from online user reviews. One research concluded that a one-star increase in Yelp application ratings translates into a $5 \%$ to $9 \%$ increase in revenues for restaurants (Luca, 2012).

Despite the popularity of online review systems, the credibility of these systems is being questioned. The reviews in these systems can be exploited, modified, or deleted by a central authority due to their centralized nature. For example, TripAdvisor was accused of deleting customer reviews that raise warnings about potential danger (Doukopil, 2017). The 
trustworthiness of these reviews is also an issue since centralized systems can be manipulated by tourism industry players such as hotels and restaurant owners (Önder \& Treiblmaier, 2018). In one case, a fine of $\$ 2.2$ million was given to an Australian hotel chain for deleting negative reviews on TripAdvisor (Williams, 2018).

Online review manipulation can come in many forms, such as removal of negative reviews, promotion of advertised reviews, and fake reviews (Salah et al., 2019). One research concluded that $38 \%$ of online reviews for certain products are fake (Mukherjee et al., 2012). This stems from the fact that all review systems to date are mostly centralized. They are subject to compromise, hacking, and tampering of their data by insiders or outsiders. They are also prone to failure and outside attacks (Salah et al., 2019). The current development of blockchain technology can solve this problem.

Based on the description above, the object used in this research is permission-less blockchain using Ethereum based on online review systems and hotels and restaurants as the tourism objects. Users add a review of the restaurant and hotels that are listed on the website to the blockchain and send it to the network. Transaction requests are taken by miners or validators. Transactions that have been compiled and validated will be sorted and packaged to the candidate block and then given a timestamp. Transactions will be stored in the ledger and distributed through the network.

Research on blockchain implementation in online consumer review has been done before. In their research, Salah et al. (2019) presented a blockchain implementation using Ethereum's smart contracts for online consumer reviews by storing the reviews' hash and the address of the reviewer on decentralized file storage called Inter-Planetary File System (IPFS). After that, the reviewer that gave a valid review is rewarded using Ether. This system can track reviews to their original reviewers, but there is no front-end application for the users to interact with (Salah et al., 2019).

This paper uses Design-Based Research (DBR) as a methodology to implement blockchain using Ethereum and to develop a web application for users to interact with (Rizal, 2021). The DBR method has several advantages, one of them is that it can lead to contextually sensitive design principles and theories (Wang \& Hannafin, 2005). The tests that are used in this paper are black-box testing and unit testing. Black-box testing is done for the website and unit testing is done for the smart contract implementation.

This paper uses Solidity as the programming language to implement smart contracts. Ganache and Truffle are used for the development of smart contracts, including the deployment and testing framework. IPFS is used to complement the blockchain as storage of images generated by the reviews because it is expensive to store a large quantity of data in the blockchain. React.js is a Javascript library that is used to develop the web application; also Web3.js connect the website to Ethereum nodes.

\section{MATERIALS AND METHODS}

This paper uses Design-based Research (DBR). The following are the stages of developing an online review system based on the blockchain using DBR as seen in Figure 1.

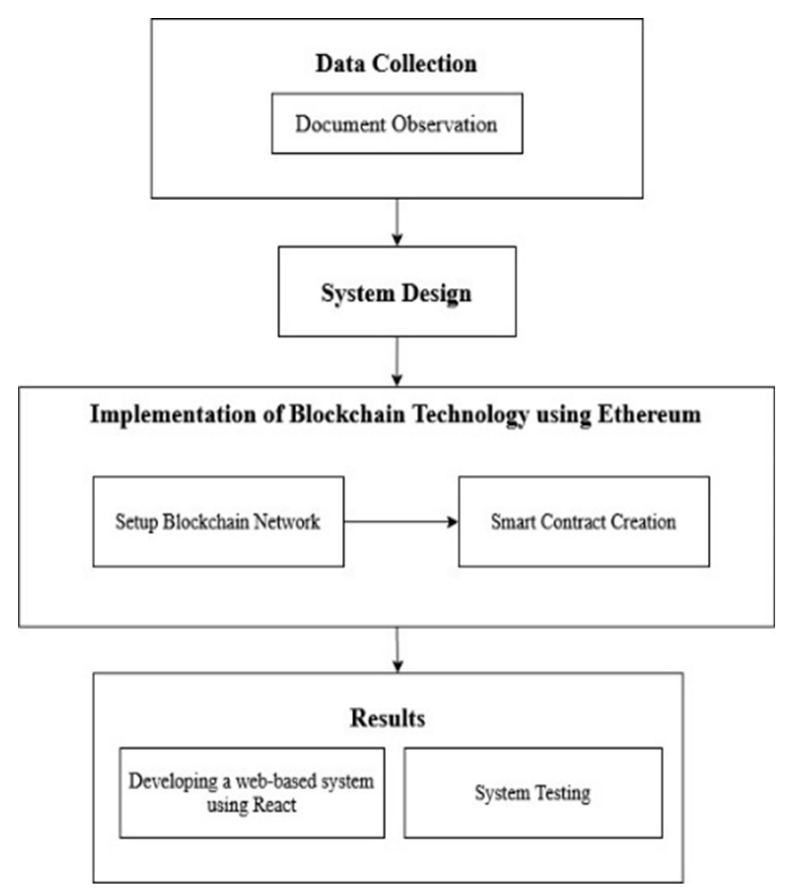

Source: (Rizal, 2021)

Figure 1. Research Stages

\section{Data Collection}

The data collection method in this research is document observation. Documents observation is done by observing and studying every documentations and report through a source that provides information about the tourism products, such as the name of the place, address, amenities, images of the place, and an overview of the workflow of the existing online review system.

\section{System Design}

Based on data collection, the researcher proposes blockchain technology to be implemented in the review posting section of tourism product's online review system. Blockchain is applied to the review storage by posting it to the blockchain using an online review system web-based application. Because it is expensive to store data with large sizes, 
such as images, IPFS will be used to store the images of the user's review. And then, the hash of those images is stored on the blockchain.

The system will run in a decentralized network and submit transactions that are immutable and secure. Transaction ordering and transaction block validation will be carried out by consensus protocol. Validated transactions are stored in the ledger and distributed to all participants' nodes on the blockchain. Permissionless blockchain type is used for participants who will join the blockchain network and can interact with the system. The participant is comprised of users who want to post a new review of tourism products to the blockchain.

An overview of the designed application workflow diagram for an online review system is in Figure 2.

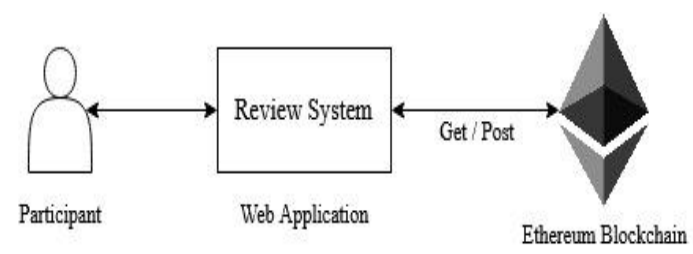

Source: (Rizal, 2021)

Figure 2. Application Workflow Diagram

Participant in the network consists of users who want to post a new review of tourism products to the blockchain. Participants interact with the review system application web interface to post new reviews to the blockchain. The participant then signs the raw transaction which consists of a new review using Metamask. After that, the transaction is broadcasted to the whole nodes in the network. Then, all the nodes in the network verify that transaction using consensus protocol. Transactions in Ethereum consist of Log and New Review Data that will be stored in the block and validated by the nodes in the network. A ledger on each node is used to record and synchronize all transactions.

Table 1 shows the mapping of the Rating enumerable. Table 2 shows the structure of the ReviewDetails struct in the smart contract. Table 3 shows the structure of the log data model.

Table 1. Mapping of Rating Enumerable

\begin{tabular}{lll}
\hline \multicolumn{1}{c}{ Field } & Type & \multicolumn{1}{c}{ Description } \\
\hline Bad & int & Mapping of 0 \\
\hline Poor & int & Mapping of 1 \\
\hline Average & int & Mapping of 2 \\
\hline Good & int & Mapping of 3 \\
\hline Excellent & int & Mapping of 4 \\
\hline
\end{tabular}

Source: (Rizal, 2021)
Table 2. Structure of ReviewDetails

\begin{tabular}{lll}
\hline Field & Type & Description \\
\hline title & string & - \\
\hline comment & string & - \\
\hline overall & int & Rating Enumerable \\
\hline service & int & Rating Enumerable \\
\hline atmosphere & int & Rating Enumerable \\
\hline cleanliness & int & Rating Enumerable \\
\hline food & int & Rating Enumerable \\
\hline images & string[3] & $\begin{array}{l}\text { Hash of images on } \\
\text { IPFS }\end{array}$ \\
\hline
\end{tabular}

Source: (Rizal, 2021)

Table 3. Structure of Log Data Model

\begin{tabular}{lll}
\hline Field & Type & Description \\
\hline reviewer & address & $\begin{array}{l}\text { Account address of } \\
\text { the reviewer }\end{array}$ \\
\hline placeName & bytes32 & $\begin{array}{l}\text { The name of the } \\
\text { place in hexadecimal } \\
\text { form }\end{array}$ \\
\hline reviewDetails & struct & $\begin{array}{l}\text { Contains } \\
\text { ReviewDetails struct }\end{array}$ \\
\hline timestamp & uint & Current time \\
\hline Source: (Rizal, 2021) &
\end{tabular}

\section{Setup Blockchain Network}

Ganache client is used for the setup process of the blockchain network. Ganache client will create a local blockchain in the local machine. Ganache environment is configurated for the development phase. In the development phase, new blocks are created when there is a pending transaction. Ganache is an efficient development tool because blocks are stored on the memory, rather than in the storage. There are two ways of setting up Ganache as a blockchain network; by installing ganache using npm install -g ganache-cli command on the terminal and then typing ganachecli to run it as shown in Figure 3, or by downloading Ganache UI from Ganache website and then installing it on the local machine as shown in figure 4.

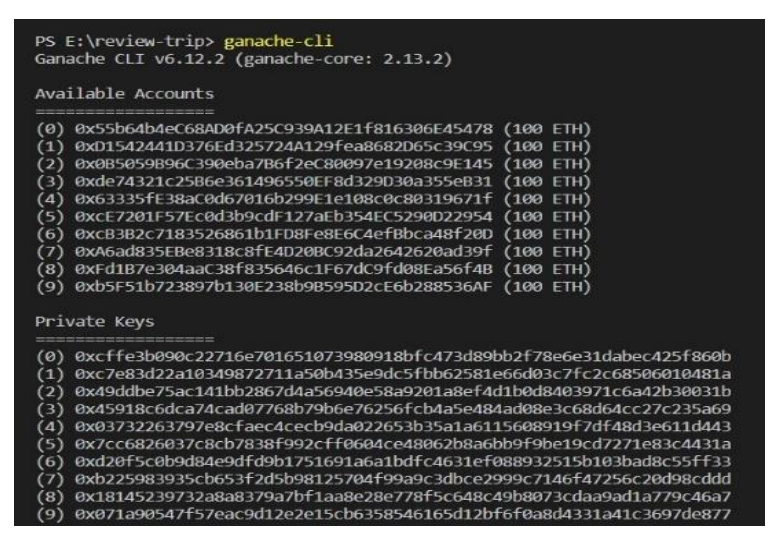

Source: (Rizal, 2021)

Figure 3. Setup Ganache Using Terminal 


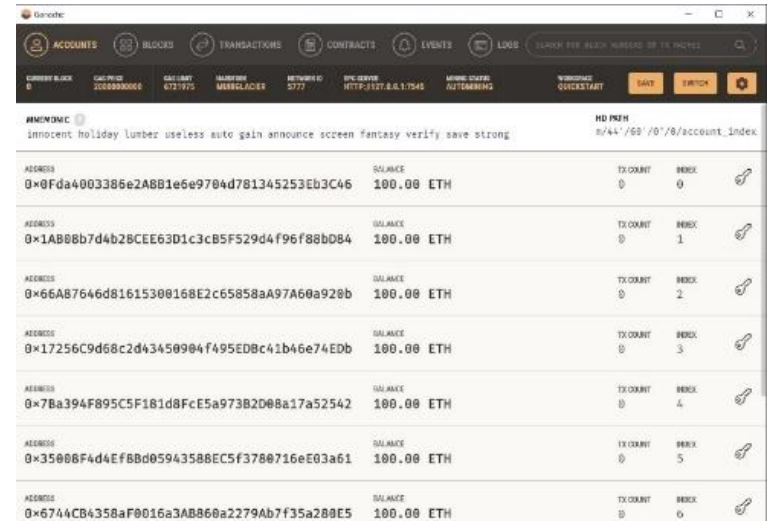

Source: (Rizal, 2021)

Figure 4. Ganache UI

\section{Smart Contracts Creation}

After setting up the blockchain network, there is a smart contract creation stage. In this stage, the Solidity programming language is used to create the smart contract for the review system.

\section{RESULTS AND DISCUSSION}

The discussion in this paper discusses the ways to get results of interface implementation using React. Accompanied by two tests, namely unit testing and black-box testing.

\section{Interface Implementation using React}

This implementation phase shows the system output that has been made. This implementation shows the user interface that can be used to view all tourism object that is available to be reviewed. This implementation is done using React, which is a Javascript library, and Web3.js to connect the website and the Ethereum nodes. Metamask is used as a gateway for the user to sign the review posting transaction to the blockchain. There are four main interface menus, which are: the main page of the website, Metamask interface for users to post their reviews, tourism object details page, and the review form page. The interfaces can be seen in Figure 5, Figure 6, Figure 7, and Figure 8.

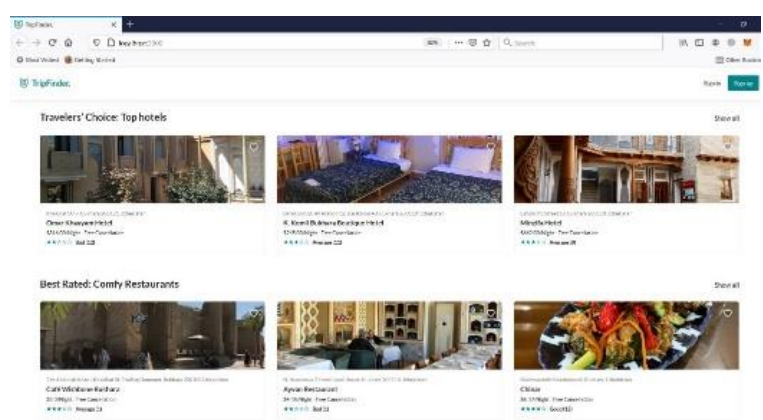

Source: (Rizal, 2021)

Figure 5. Main Page

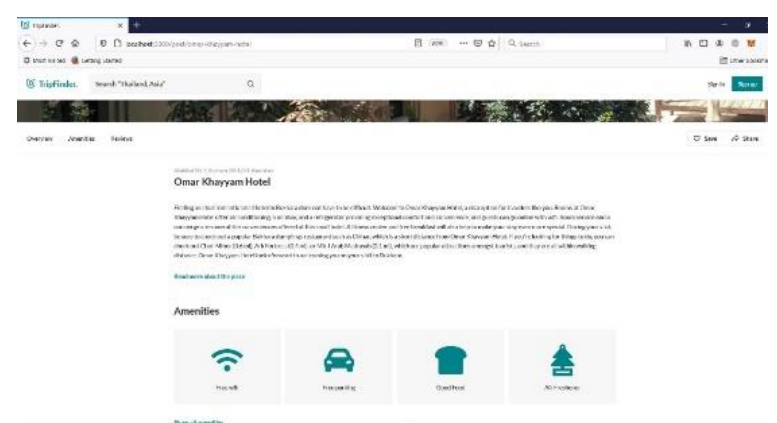

Source: (Rizal, 2021)

Figure 6. Hotel Information Displayed in The Website

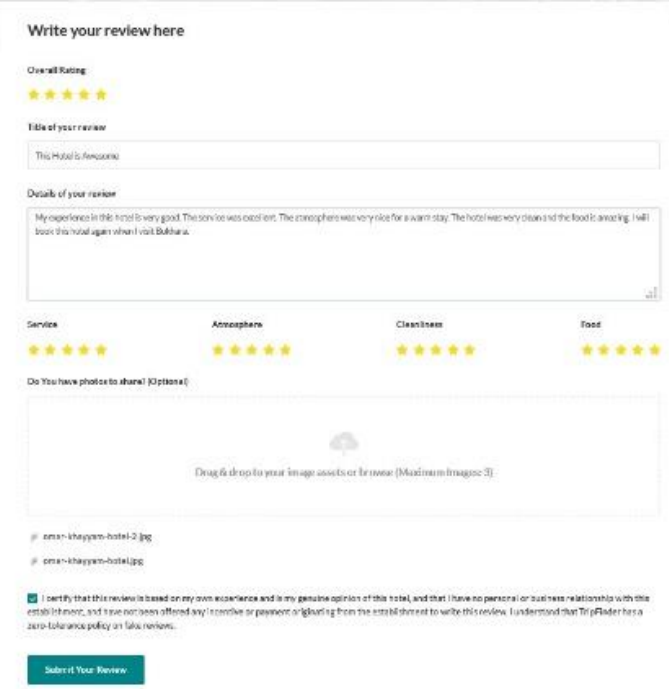

Source: (Rizal, 2021)

Figure 7. Review Form

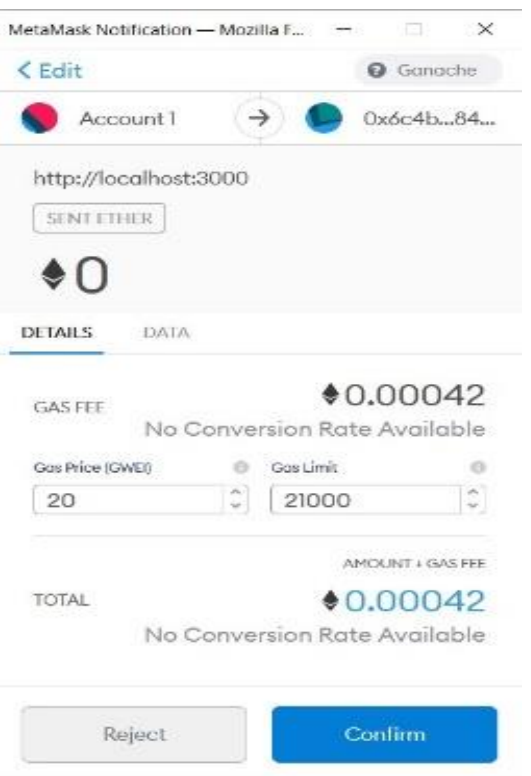

Source: (Rizal, 2021)

Figure 8. Metamask Interface to Confirm Review Posting 


\section{Testing}

The performance of the system can be seen from the results of system testing, which are unit testing and Black-Box testing. The following section will display the result of each testing method.

\section{a. Unit Testing}

Unit testing of the smart contracts is done using the Truffle framework. To unit test, the smart contracts, unit test cases have to be designed and the test environment for the unit under test has to be developed. The test cases were developed to determine whether the smart contract can post a review to the blockchain, display reviews that have been posted to the blockchain and whether the logging system runs accordingly. The smart contract that was created pass all three test cases, as shown in Figure 9.

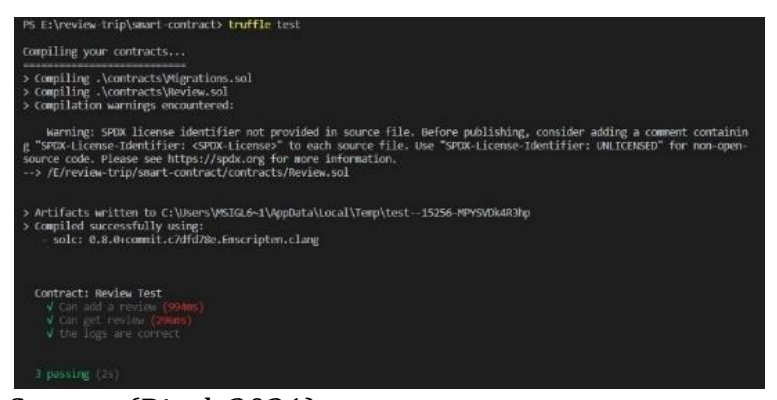

Source: (Rizal, 2021)

Figure 9. Unit Test Results

\section{b. Black Box Testing}

Black box testing is done to determine whether all website functions run properly according to the functional requirements that have been designed. The black box testing method is done by deriving a set of input conditions that fully utilize all functional requirements for a program. The results of the testing using the black-box method can conclude that all system interface components are functioning accordingly. Table 4 is the black box test results. Status: $\mathrm{S}$ for success and $\mathrm{F}$ for failure.

Table 4. Result of black-box testing

\begin{tabular}{|c|c|c|c|c|}
\hline Function & Input & Expected Output & Output & Result \\
\hline View Details & $\begin{array}{l}\text { User click "View Details" } \\
\text { button on the main page }\end{array}$ & $\begin{array}{l}\text { Displaying the details } \\
\text { of the object chosen }\end{array}$ & $\begin{array}{l}\text { Displaying the details } \\
\text { of the object chosen }\end{array}$ & $\mathrm{S}$ \\
\hline Overview & User click "Overview" button & $\begin{array}{l}\text { Displaying the } \\
\text { description of the } \\
\text { object chosen }\end{array}$ & $\begin{array}{l}\text { Displaying the } \\
\text { description of the } \\
\text { object chosen }\end{array}$ & $S$ \\
\hline Amenities & User click "Amenities" button & $\begin{array}{l}\text { Displaying the } \\
\text { amenities that an } \\
\text { object has }\end{array}$ & $\begin{array}{l}\text { Displaying the } \\
\text { amenities that an } \\
\text { object has }\end{array}$ & $\mathrm{S}$ \\
\hline Write a Review & $\begin{array}{l}\text { User click "Write a Review" } \\
\text { button }\end{array}$ & $\begin{array}{l}\text { Displaying the review } \\
\text { form page }\end{array}$ & $\begin{array}{l}\text { Displaying the review } \\
\text { form page }\end{array}$ & $S$ \\
\hline Submit a Review & $\begin{array}{l}\text { User click "Submit a Review" } \\
\text { button after filling all of the } \\
\text { required fields on the Review } \\
\text { Form }\end{array}$ & $\begin{array}{l}\text { Displaying the pop-up } \\
\text { Metamask Interface }\end{array}$ & $\begin{array}{l}\text { Displaying the pop-up } \\
\text { Metamask Interface }\end{array}$ & $\mathrm{S}$ \\
\hline Submit a Review & $\begin{array}{l}\text { User click "Submit a Review" } \\
\text { button without filling the } \\
\text { required fields on the Review } \\
\text { form }\end{array}$ & $\begin{array}{l}\text { The form will display } \\
\text { a "This field is } \\
\text { required!" message in } \\
\text { every blank field }\end{array}$ & $\begin{array}{l}\text { The form will display } \\
\text { a "This field is } \\
\text { required!" message in } \\
\text { every blank field }\end{array}$ & $\mathrm{S}$ \\
\hline
\end{tabular}

Source: (Rizal, 2021)

\section{CONCLUSION}

In this paper, the implementation of the permission-less type of blockchain using Ethereum has been carried out successfully. The development of blockchain implementation is displayed in the form of a web application based on the workflow of the online review system of tourism products. Web applications run on a decentralized network using React library from Javascript and the data is stored in a distributed ledger. The stored data is in the form of new reviews and event logs. Each transaction that is carried out will produce a status, transactionHash, transactionIndex, blockHash, blockNumber,
contractAddress, cumulativeGasUsed, gasUsed, and logs. The data and transactions are immutable, accountable, and transparent. Based on system testing using Black-Box Testing, features on the website run successfully. Using unit testing, the features that are provided in the smart contracts also run successfully. Unit testing is done by checking whether the smart contracts can pass three test cases that were created. The result is that the smart contracts pass the three test cases that were created; meaning it can add a review to the blockchain, it can display review that was stored on the blockchain, and the logging system run 
accordingly. Unit testing of the smart contract is carried out using Truffle Framework.

\section{REFERENCES}

Alexa. (2020). Top 500 of the U.S. most visited websites. https://www.alexa.com/topsites/countries/ US

Doukopil, T. (2017, November 2). TripAdvisor accused of deleting reviews that raised red flags. $\quad C B S \quad N e w s, \quad$ News. https://www.cbsnews.com/news/tripadviso r-accused-of-deleting-reviews-that-raisedred-flags/

Luca, M. (2012). Reviews, Reputation, and Revenue: The Case of Yelp.Com. SSRN Electronic Journal. https://doi.org/10.2139/ssrn.1928601

Mccarthy, L., Stock, D., \& Verma, R. (2010). How Travelers Use Online and Social Media Channels to Make Hotel-choice Decisions. 10(18).

Mukherjee, A., Liu, B., \& Glance, N. (2012). Spotting fake reviewer groups in consumer reviews. WWW'12 - Proceedings of the 21st Annual Conference on World Wide Web, 191-200. https://doi.org/10.1145/2187836.2187863

Önder, I., \& Treiblmaier, H. (2018). Blockchain and tourism: Three research propositions. Annals of Tourism Research, 72, 180-182. https://doi.org/10.1016/j.annals.2018.03.00 5

Reyes-Menendez, A., Correia, M. B., Matos, N., \& Adap, C. (2020). Understanding Online Consumer Behavior and eWOM Strategies for Sustainable Business Management in the Tourism Industry. Sustainability, 12(21), 8972-8986.

https://doi.org/10.3390/su12218972

Rizal, M. R. R. (2021). A Blockchain-Based Online Review System of Tourism Products. Gunadarma University.

Salah, K., Alfalasi, A., \& Alfalasi, M. (2019). A Blockchain-based System for Online Consumer Reviews. INFOCOM 2019 - IEEE Conference on Computer Communications Workshops, INFOCOM WKSHPS 2019, 853858.

https://doi.org/10.1109/INFCOMW.2019.88 45186

Wang, F., \& Hannafin, M. J. (2005). Design-based research and technology-enhanced learning environments. Educational Technology Research and Development, 53, 5-23. https://doi.org/10.1007/BF02504682

Williams, D. (2018). Australian hotel chain fined $\$ 2.2$ million for manipulating TripAdvisor reviews. CNN Travel. https://edition.cnn.com/travel/article/austr alia-tripadvisor-hotel-fined-trnd/index.html 